Article

\title{
Mobile Peoples: Transversal Configurations
}

\author{
Engin Isin ${ }^{1,2}$ \\ ${ }^{1}$ School of Politics and International Relations, Queen Mary University of London, London, E1 4NS, UK; \\ E-Mail: engin.isin@qmul.ac.uk \\ 2 University of London Institute in Paris, 75340 Paris, France
}

Submitted: 24 November 2017 | Accepted: 12 February 2018 | Published: 29 March 2018

\begin{abstract}
This essay is an attempt to think 'mobile peoples' as a political concept. I consider mobile peoples as a norm rather than an exception and as political subjects rather than subject peoples. After discussing the tension between 'mobile' and 'peoples', I draw on lan Hacking's historical ontology for understanding how a people comes to be. For understanding how the people comes to be, or rather, how the tension between a people that constitutes itself as a whole and those peoples that remain as residual parts, I draw on Giorgio Agamben, Jacques Rancière, and Ernesto Laclau as authors who identified this tension as a fundamental problem of 'Western' political thought. Yet, their inattention to territory draws me to James Scott whose work on early states challenges how we have come to understand the people as sedentary in the first place. His account of how 'barbarians' (mobile peoples) came to be seen as a threat to sedentary peoples enables us to understand that tension. Then a path opens toward thinking about mobile peoples as a political concept.
\end{abstract}

\section{Keywords}

a people; mobile peoples; territory; the people; state

Issue

This article is part of the issue "The Transformative Forces of Migration: Refugees and the Re-Configuration of Migration Societies", edited by Ulrike Hamann and Gökçe Yurdakul (Humboldt University of Berlin, Germany).

(C) 2018 by the author; licensee Cogitatio (Lisbon, Portugal). This article is licensed under a Creative Commons Attribution 4.0 International License (CC BY).

\section{Introduction}

Over the last two decades research in fields such as migration studies, refugee studies, citizenship studies and mobility studies has demonstrated that human mobility involves complex movements: iterative migrations across countries; massive relocations and displacements within countries and across their cities and regions; intricate combined and uneven geographies; interwoven histories of recurrent and seasonal movements; increasing use of mobile technologies in practices of governance and resistance; intersections of affective, cultural and political identities, and hybrid cultural, linguistic, and social formations (Cresswell, 2006; Elliott \& Urry, 2010; Hannam, Mostafanezhad, \& Rickly-Boyd, 2016; Merriman, 2012). This research has shifted our attention away from migration as a one-way movement often across and within state borders. Instead, how mobile peoples, of all kinds and in multiple ways, produce novel social, political and cultural lives, knowledge and practices, and thereby drive political change has become an issue (Adey, Bissell, Hannam, Merriman, \& Sheller, 2014; Gold \& Nawyn, 2013; Isin \& Nyers, 2014).

Thus, scholars regard the often-cited figures such as that nearly a quarter of a billion people live in countries other than their birth (as of 2015) or that this is a 41 per cent increase since 2000 rather sceptically. For these are not mere descriptions of human mobility (UN, 2015). They are also ascriptions that shape how we understand human mobility as one-way movement between or across states. The uses of statistics for public policy in migration and immigration and in general concerning human mobility understood as one-way crossstate migration are fraught with struggles over meanings and functions of such figures (Boswell, 2009). There are increasingly critical studies of the ways in which migration, immigration and mobility are constituted as problems to be managed, solved, and contained rather than 
seeing mobile peoples as political subjects who are creating new forms of life (Geiger, 2013; Manderscheid, 2016; Pécoud, 2015). There are also studies critical of constituting mobility as an independent fact from reflexive and agentic involvement of people right across the spectrum from mobile to immobile (Frello, 2008). Perhaps because of this shift national and international authorities, agencies, and organisations are beginning to recognize that, rather than being a problem that can be solved or managed, the mobility of people is shaping and structuring the terms of contemporary political life.

That these critical studies are changing our views of people on the move beyond Eurocentrism and statecentrism is a welcome development (Lucassen \& Lucassen, 2014, 2017). Perhaps this is now the moment that we ask a historical question regarding why 'mobile peoples' were constituted as an exception (and a problem) in the first place. This might involve thinking big about mobile peoples as Elizabeth Zanoni (2017) put it when describing the pioneering work of Donna Gabaccia (1999). I want to argue here that it requires genealogical investigations of the concept of 'people' and the functions it has come to perform. There are certainly different ways to approach this question but a historical approach to 'mobile peoples' as a political concept requires two moves.

First, exploring the possibilities of recognizing 'mobile peoples' as a norm rather than exception goes against the grain of dominant perspectives. The concept 'people' itself already signifies immobile, sedentary, and enclosed body politic bounded within a territory. Thus, seeing 'mobile peoples' as a norm requires exploring how 'people' has come to acquire its dominant signification in the first place. Second, developing 'mobile peoples' as a political concept that restores political subjectivity to mobile peoples requires exploring the conditions under which 'mobile peoples' have become objects of government. This means recognizing the difficulties of the concept 'people' and the differences between the people and peoples as its parts.

The first move-to consider 'mobile peoples' as a norm rather than an exception-may appear easier than the second move-to consider 'mobile peoples' a political subject. We can, for example, argue that humans have always been on the move (Feldman, 2015; Panayi \& Virdee, 2011). Or, as Jürgen Osterhammel (2009) has argued, the emergence of 'modern' population movements in the nineteenth and twentieth centuries were the foundations of our age. Or, we can appeal to the uniqueness of the twenty-first century to argue that the concept 'mobile peoples' covers not only those for whom crossing all sorts of borders is decisive for the way in which they live their lives, but also those whose lives are implicated in the lives of those who move. It includes those who move by force or by choice, those who cut ties or stay in touch, those who return once or many times, as well as those who are left behind. We can argue that there are categories of mobile peoples including diplomats, families, investors, pensioners, refugees, students, travellers, tourists, and workers who dwell or inhabit these various mobilities. We can accept it as a social fact that, for example, grandparents whose livelihood depends on remittances from their migrant grandchildren are as much a part of this mobility as their grandchildren. We can argue that mobility shapes more than just the lives of those who are on the move. Consequently, we can argue that it also has an impact on social and political institutions and practices through which people arrange and govern their lives.

All these arguments are possible. But I wonder if we are not valorizing ostensible facts rather than asking questions about our changing perspectives on peoples living mobile lives? To put it differently, is there not a problem in appealing to autonomous facts without considering the conditions under which such facts have come into being (Buscher, Urry, \& Witchger, 2011; Cresswell, 2006; Elliott \& Urry, 2010)? Do we not need to become sceptical about making such appeals without considering how, where, and when mobile peoples have become a concern or even a problem for various governmental authorities and under which new modes are mobile peoples being governed? (Endres, Manderscheid, \& Mincke, 2016). If we are to articulate the transformative effects of people living mobile lives on political life in the present, we will need to have a critical approach towards the terms under which we are describing mobile peoples. Thus, rather than making an appeal for mobile peoples as a norm rather than an exception based on ostensibly independent facts I want to discuss how we should approach the concept 'people' in the first place. That is why the next two sections will make up the bulk of this essay examining political genealogies of the concept of people-first 'a people' and then 'the people'. We shall see that the passage from 'a people' to 'the people' is not only a passage through which a people becomes a sovereign political subject but also a sedentary (as opposed to mobile) political subject.

\section{What Is $a$ People?}

What is a people? This is a difficult question because the naming of a people is always a performative rather than a descriptive act. The naming of a people is a double act: as it names a people it also mobilizes the named to act as a people. Here lan Hacking's performative approach to how kinds of people appear in language and how this language invites people into becoming one is immensely helpful. Hacking captures this process by using two terms: making up a people and looping effect (Hacking, 2007, pp. 289-290). Both terms owe to a performative understanding of the relations between words and things that Hacking calls 'historical ontology' both to indicate his debt to Michel Foucault (1997) and to signify his own approach that he calls 'dynamic nominalism'. Historical ontology also owes to Friedrich Nietzsche (2001) and J.L Austin (1962) but I leave these influences out of this 
discussion and focus briefly on Hacking and why his work is essential for the question I am articulating.

Hacking begins with the assumption that words and things are effects of each other (Hacking, 2002, p. 3). To understand these effects we need to understand beings and coming into beings as historical developments. The beings that become things such as classifications, ideas, peoples, or institutions are all objects of historical ontology in the sense that we cannot understand these things without tracing their histories. These objects make sense only insofar as we understand how they came into being and acquired their meanings. For example, Hacking says, 'the idea that peoples just separate naturally into overarching racial, ethnic, or linguistic groups is largely a product of a recent invention, the nation state' (Hacking, 2007 , p. 289). There is no reason to assume that we will find these things in the past in the same manner in which we understand them in the present or that these things in the present are evolved versions of the things in the past. Thus, historical ontology considers 'kinds of people' as having come into being historically as invented descriptions through which people constitute themselves as acting beings. Such descriptions become embedded in human practices and provide ways of acting and being in the world. All acts are acts performed under a description. If new descriptions come into being new possibilities for action come into being in consequence (Hacking, 2002 , p. 108). It is in this sense that the act of naming a people is an act of 'making up a people'. Unless people take up these descriptions and act upon them and each other a description would not have any performative force. When people act they interact with descriptions and this creates a looping effect where descriptions acquire performative force. The name (words) and the named (things) interact. Hacking insists that this process is dynamic in the sense that there is no static moment in the looping effect where the named can be said to be the effect of the name or vice versa. Instead, the name and the named are constituted dynamically.

Hacking names five dynamic moments through which words and things become effects of each other. First, a description appears about the kind of people. Second, people begin to act under this description. Third, institutions emerge to manage the kind of people acting under this description. Fourth, knowledge about the kind of people in question appears: their characteristics, fierce or docile, artistic or warlike, artisans or hunters etc. Fifth, authorities, expertise, and administration of people emerges that regulate the kind of people acting under this description. A historical ontology of a kind of people means to investigate how and when these five dynamic moments were present and how its description became possible and was transformed. Hacking gives examples of various kinds of people (Hacking, 2007, p. 285). He speaks, for example, about the avalanche of numbers in the nineteenth century on various categories of people: murderers, thieves, prostitutes, drunks, vagrants, insane, poor, and all sorts of deviants. Where did these people come from? Did they not exist before the nineteenth century in some form? Hacking says things that people did to get classified existed historically (e.g., stealing, killing, drinking) but how those things were used to describe, enumerate and classify people are made up and change often. He says 'even national and provincial censuses amazingly show that the categories into which people fall change every ten years. Social change creates new categories of people, but the counting is no mere report of developments. It elaborately, often philanthropically, creates new ways for people to be' (Hacking, 2002, p. 100). The categories that Hacking mentions involve many different 'ways to be' such as those of sexuality or ethnicity or race. Hacking, for example, says 'the homosexual and the heterosexual as kinds of persons (as ways to be persons, or as conditions of personhood) came into being only toward the end of the nineteenth century' (Hacking, 2002, p. 103). Historically there were sex acts between individuals, but it came under familiar and recognizable (sayable and visible) descriptions only in the nineteenth century. And there is no guarantee that these descriptions will live forever. So his claim:

Is not that there was a kind of person who came increasingly to be recognized by bureaucrats or by students of human nature, but rather that a kind of person came into being at the same time as the kind itself was being invented. (Hacking, 2002, p. 106)

So, the argument is not that a kind of people never existed before and came into being at a certain moment. Nor is it that a kind of people always existed and that it was named in a particular moment. Rather, at a certain moment in history people did not experience themselves in this particular way, they did not interact with other people in this way, and were not treated by knowledge, institutions, authorities under this description. Thus, the making up people is a complex performative event that requires historical ontology to investigate.

When Hacking talks about 'making up people' he means kinds of people. These are kinds of people such as murderers, dandies, flaneurs, blacks, homosexuals, and so on that constitute 'parts' of a 'whole'. These kinds of people as 'parts' are unimaginable unless there are kinds of people who have been constituted as a 'whole'. This is a problem that Hacking does not address. A people (or peoples) can be described only when there is a difference between peoples (parts) and the people (whole). The people as a whole involves a more complicated historical ontology than Hacking implies including the relation between parts and wholes. This is because the complex interplay between words and things that Hacking addresses involves power relations and there are plays of domination in these descriptions. The description 'black' or 'gay' is not only a description under which a people will act but also an asymmetrical signifier under which a people will be acted upon-will be subjected to government. Moreover, it is one thing to see how the category 
of murderers has come about; it is another to understand how the category Jewish or French people was brought into being. The question that opens up here is not only the invention of kinds of people but also with the invention of the people. To put it differently, the question what is a people inevitably leads to the question what is the people.

Hannah Arendt in the 1940s and Michel Foucault in the 1970s came to this problem of the difference between a people and the people (Isin, 2012). Arendt famously argued that it was in the nineteenth century that the nation as a people conquered the state. Her genealogy of race-thinking, for example, led her to understand the dangers of instituting a state as a nation. Similarly, Foucault investigated how nations became the nation in the nineteenth century. For both the making up of peoples in Europe as nations generated peoples as 'minorities'. What we learned from Arendt and Foucault is that a genealogy of 'the people' inevitably leads to the kinds of people it generates.

\section{What Is the People?}

How does a people become a people? Does a people become only that which it is? If so, then what is it? How can we know: (1) What a people in general is? (2) What this or that people is? (3) What we ourselves are? (Heidegger, 2012)

It is not perhaps surprising that before Arendt in the 1940s and Foucault in the 1970s, Martin Heidegger was confronted by a question in the 1930s of the difference between a people and the people. For the purposes of illustrating the difficulties of considering the concept 'mobile peoples' we would need a historical ontology from ancient Greek demos to Roman plebeians to medieval Italian popolo illustrating how various peoples became remainders or residuals of the people. Margaret Canovan (2005) traces precisely this particular history. She reveals a constitutive tension between 'the people' which differentiates itself from the unruly, poor, rapturous and eruptive peoples. She notes that the respectable, unified, and virtuous stories of 'the people' are always narrated against the unruly mob or herd. Canovan already provides us the view that the difference between a people and the people or even a passage from a people to the people involves domination. Alain Badiou puts this starkly when he says:

The word 'people' was only suitable for the conquering powers, elated by the conquest itself: 'the French people,' 'the English people,' yes....But the Algerian people, the Vietnamese people? No! And even today for the Israeli government, 'the Palestinian people'? An even louder no. (Badiou, 2016, pp. 22-23)

Yet, it was Giorgio Agamben (2000) who identified this tension as a constitutive question of 'Western' politics.
Agamben insists that 'any interpretation of the political meaning of the term people ought to start from the peculiar fact that in modern European languages this term always indicates also the poor, the underprivileged, and the excluded. The same term names the constitutive political subject as well as the class that is excludedde facto, if not de jure-from politics' (Agamben, 2000, p. 29). From the beginning of political thinking about 'people' there is an ambiguity whether it means the constitutive dominant (the people) or the dominated (a people) or both. For Agamben then 'such a widespread and constant semantic ambiguity cannot be accidental: it surely reflects an ambiguity inherent in the nature and function of the concept of people in Western politics' (Agamben, 2000, p. 31). According to Agamben 'this also means, however, that the constitution of the human species into a body politic comes into being through a fundamental split and that in the concept of people we can easily recognize the conceptual pair identified earlier as the defining category of the original political structure: naked life (people) and political existence (People), exclusion and inclusion, zoē and bios' (Agamben, 2000, pp. 31-32). Agamben concludes that:

The concept of people always already contains within itself the fundamental biopolitical fracture. It is what cannot be included in the whole of which it is a part as well as what cannot belong to the whole in which it is always already included (Agamben, 2000, p. 32, emphasis original)

Thus, 'If this is the case-if the concept of people necessarily contains within itself the fundamental biopolitical fracture-it is possible to read anew some decisive pages of the history of our century' (Agamben, 2000, p. 33). Although Agamben identifies this fracture and insists on reading anew certain events of the twentieth century, he also implies that this fracture is so fundamental that it requires examining the entire 'Western' political history. I am aware of the massive debate about Agamben's interpretations of Arendt and Foucault and concerning his differentiation between zoē and bios but I consider his point about the fundamental fracture in Western political theory as a serious challenge to think about people genealogically.

I will locate mobile peoples within this fracture after I discuss Jacques Rancière and Ernesto Laclau who have taken up this challenge seriously. Both start from the proposition that there is indeed a fundamental fracture or tension exists between 'the people' as a whole and a people or peoples as its parts. I will briefly discuss how each attempts to work this tension to use it critically to think about 'people' as a political concept.

Rancière's description of the whole and parts of ancient politics is well known. I'll briefly summarize here how he addresses the fundamental fracture of Western politics that Agamben identifies. If indeed we can describe the 'whole' as any given polity and 'parts' as 
its constitutive elements how is their relation decided? For Rancière what gives rise to politics is the dispute about what counts as parts. He says dominant interpretations of ancient politics hitherto read this politics arising from an already constituted polity and its already existing conflicts; however, he says, it is actually the other way around. Any polity is founded on politics that arises from what he calls counting the parts that constitute it. Politics involves counting of parts and its disputes about what counts that constitutes a polity.

Let's recall that for Rancière there are two ways of counting: arithmetic and geometric. These two ways are not so much as descriptions of counting as ways of approaching how one counts. It enables Rancière to schematize two ways of thinking about politics. An arithmetic counting assumes that all is accounted for (hence always a false count); a geometric counting counts those parts that have no part. When counting is arithmetic (as in what is counted) it accounts for what is given; when it is geometric (as in what counts) it accounts for what is not given. Yet, and this is crucial, counts are always false counts as they fall short of considering of what actually counts. Politics arises from this paradox of being unable to and yet need to count parts (Rancière, 1998, p. 6). It arises when those who have no part actually struggle to make themselves count (Rancière, 1998, p. 9). What is political about making themselves count is that the parts that have no part identify themselves to be the whole of the polity. It is this audacious identification that is political. This is, for example, the historical significance of demos in Athenian politics. The claim of demos is not only to make itself count but also to constitute itself as the whole. So, then the language of those who have no part is not about an essential struggle between the rich and the poor, between this and that class, or between this and that social group. Politics is not an opposition between the rich and the poor. Rather, politics is the interruption of an order of domination by the institution of a part of those who have no part (Rancière, 1998, p. 11).

So far in this account we have spoken about peoples or the people. For translating whole and parts language into peoples and the people categories Rancière introduces two terms: equality and wrong. The struggles of those who have no part to institute themselves as a part is based on their claims to equality and it arises from their declaration of wrong, an injustice. The claim to inequality is necessary for the declaration of wrong and that declaration is impossible without the assumption of equality of speech and capacity, an equal part in dispute. If indeed 'politics exists wherever the count of parts and parties of society is disturbed by the inscription of a part of those who have no part' it begins when the equality of anyone and everyone is inscribed in the liberty of the people (Rancière, 1998, p. 123). And 'this liberty of the people is an empty property, an improper property through which those who are nothing purport that their group is identical to the whole of the community' (Rancière, 1998, pp. 123-124). So, the passage of a people to the people, its claim, is the origins of politics (or how 'Western' politics perceives its origins).

What is this whole, that a people identifies with? Rancière says that 'the people' has a double embodiment: it is both the name of a whole polity and the name of a part of that polity. The gap between these two names of the people is the site of a grievance (Rancière, 1995, p. 97). From our perspective of thinking about mobile peoples as a people, Rancière's key argument is that while ancient politics understood this gap, modern politics cannot tolerate it. Modern politics cannot accept that the people simultaneously can be both dominant and dominated, whole and part, sedentary and mobile (Rancière, 1995, p. 99). For Rancière in modern politics 'the appearance of the people must be strictly confined to the attributes of sovereignty or the appearance of sovereignty dissolved in favour of the realities of the people as producers' (Rancière, 1995, p. 99). So, then this gap between a people and the people is both a challenge to and trigger of politics; ancients understood it, moderns cannot tolerate it.

Although not concerned with the ancient origins or lineages of modern politics, Laclau is very close to Rancière in his attempt to work this tension for understanding something key about politics. At the centre of his argument is the concept of socio-political 'demands' articulated by the dominated to the dominant (hegemonic) order. The dominated articulate an exclusion or deprivation as their grievance and this articulation as a demand constitutes a people (Laclau, 2005, p. 123). As with Rancière then a people is not a given sociological concept but something that arises from within politics. This recognizes that there is a constitutive asymmetry between a polity understood as a whole (the populus) and the dominated as its part (the plebs). For Laclau, as for Rancière, it is crucial that the plebs identify themselves with the populus as the polity as a whole (Laclau, 2005, p. 224). Thus, as in Rancière, the plebs function both as part of a whole and a part that is the whole (Laclau, 2005, p. 225). The logic of hegemony that arises from this tension between the part and the whole implies that the whole is 'contaminated' by the part and the part contains the whole. The analytical distinction between the universal and the particular as though they are mutually exclusive opposites is thus false and belies the logic of hegemony (Laclau, 2005, p. 226). For Laclau the ambiguity of 'the people' both as the populus and the plebs is not a logical contradiction but expresses the logic of hegemony. Where Laclau differs from Rancière is that while Rancière seems to assume that the constitution of the part that has no part will always invoke a politics of emancipation Laclau does not think that can be determined theoretically (Laclau, 2005, p. 246). Laclau also differs from Rancière in insisting on limits of philosophical analysis and the necessity of sociological investigation of the ways in which the logic of hegemony constitutes a people (Laclau, 2005, p. 248).

What is important in both Rancière and Laclau, from our point of view, is their insistence on taking the ten- 
sion between parts and the whole as the constitutive tension of politics. But I find it difficult to accept their insistence that politics inevitably if not essentially involves the construction or formation of a people as a wholethe people. More specifically, the requirement that parts must identify with the whole to take part always justifies becoming a kind of people that the people already is. If, as Rancière says, there is no politics beyond and outside this configuration of the whole and its parts and that 'there is only the order of domination or the disorder of revolt' then how does the configuration itself gets disrupted (Rancière, 1998, p. 12)? If we follow Rancière and Laclau in insisting that the whole (the people) and its parts (peoples) are implicated in each other then to what extent can we imagine a people that will not identify with the people? Both Rancière and Laclau define politics as rupture in a given order but why this rupture should be conceived as the formation of the people, as identification with the whole, is never explained. Laclau says that the formation of a people involves an act of institution and as an act it does not derive its force 'from any logic already operating within the preceding situation' and that 'what is crucial for the emergence of "the people" as a new historical actor is that the unification of plurality of demands in a new configuration is constitutive and not derivative' (Laclau, 2005, p. 228). It sounds like Laclau is overcoming the tension and we can, with some modifications, agree with him. But he then adds 'it constitutes an act in the strict sense, for it does not have its source in anything external to itself' (Laclau, 2005, p. 224). Whether we work the tension between a people (or peoples) and the people as a gap that constitutes politics (Rancière) or a contamination that constitutes polity (Laclau) we are still left with a fundamental fracture that is always signified against a whole that is already constituted. This leaves mobile peoples with no possibility beyond either becoming sedentary or remaining outside politics.

\section{Mobile Peoples: Transversal Configurations}

There are two obstacles to understanding mobile peoples with Rancière and Laclau and, for that matter, with Agamben and perhaps even Hacking. First, in all their theorizing a people remains without geography. Each emphasizes the importance of understanding a people with their history, but their peoples remain without geography. Warning against writing peoples without history, each practically treats peoples without geography. What I mean by this can be illustrated by James Scott's remark that 'a great many apparently ethnic names turn out to be, when translated literally, a description of a people's geography, applied to them by state discourse: "hill people," "swamp dwellers," "forest people," "people of the steppes"' (Scott, 2017). Or, we can add contemporary examples: people without permanent address, people without papers, people without property, people without nationality, and most troubling of them all people without states. Gilles Deleuze and Felix Guattari (1987) said 'history is always written from the sedentary point of view and in the name of a unitary State apparatus, at least a possible one, even when the topic is nomads.' We need to see that geography-the ways in which people constitute themselves through space-is just as constitutive as history for how a people comes to be. What distinguishes peoples such as hill peoples or forest peoples or people without papers is that they are described by sedentary peoples, that is, from the perspective of states organized as a bounded a territory. For all the tensions, contaminations, gaps, and fractures that are identified between the whole and its parts by Agamben, Rancière, and Laclau what is not recognized is that from the perspective of the state a 'proper' people is always seen as coextensive with a given territory. Stuart Elden's (2013) genealogy of the concept of territory painstakingly documents its social production. He traces how juridico-political discourse produces state as a bounded territory as the name of that space. We need to see that 'Western' political thought takes that concept of territory as granted, perhaps seeing it like a state as Scott (1999) describes it. But seen from another perspective (more on that below) the parts that don't count often are mobile peoples who were subjected to domestication to become a part of the people. The territory that bounds the people as a whole differentiates mobile peoples as residual or remainder parts. The remainders of the whole, the parts that don't count remain as mobile peoples: nomads, seafarers, pirates, travellers, migrants, refugees, itinerants, gypsies, wanderers. These mobile peoples find it impossible to constitute themselves as political subjects precisely because they cannot be coextensive with a territory as they remain peoples without geography. The idea of territory as a bounded space under the control of $a$ people organized through a state that constitutes them as the people of that state remains the dominant image in political thought and overcoming it (i.e., thinking differently about histories and geographies of peoples) is a difficult task.

The second obstacle to understanding the fracture between peoples and the people is that the difference is seldom between a people that constitutes itself as the dominant (the people) and the other as the dominated (peoples). It is often more fine-grained than that opposition implies. It is more like a spectrum of various peoples and how individuals take (and give) positions across this spectrum: strangers, outsiders, and aliens. Often people move through (or find themselves in) multiple and intersecting positions across this spectrum (Isin, 2002, 2017). As Scott (2017) puts it 'a great many barbarians, then, were not primitives who had stayed or been left behind but rather political and economic refugees who had fled to the periphery to escape state-induced poverty, taxes, bondage, and war.' Citizens can become barbarians and barbarians can become citizens.

Scott's work on the history of early states is a major contribution to thinking about how a people comes to 
be and how a differentiation between the people and peoples is often established along sedentary versus nomadic, state versus non-state, and civilized versus barbarian lines (Scott, 2009, 2017). Scott (2017) recognizes that what we most know about historical geography of peoples have been written from the perspective of sedentary peoples settled in each territory as a state. How these peoples developed control over a territory by knitting together various patchwork of hinterlands and peripheries and subjugating peoples in these spaces into state peoples provides a glimpse of how subjugated peoples are almost invariably mobile peoples-barbarians-who were not simply outside the state but were subjugated in various differentiated categories. Scott uses 'barbarian' as a generic concept of mobile peoples whom states were either not able to subjugate or, more interestingly, actually created as residual peoples who escaped subjugation. Scott's seemingly simple but effective narrative is about how we might see history from the perspective of those whom were subjugated to states-a historical geography of mobile peoples. Scott repeatedly reminds us that history has been written from the perspective of sedentary peoples as a norm. Yet, as he illustrates, since the emergence of early states (not only between Euphrates and Tigris rivers but also along Yellow River and the alluvial plains of South America over the last ten thousand years or so) only in the last three or hundred years that states and their sedentary peoples could be said to have established a norm. But as far as a 'deep' history of states is concerned this is relatively recent and exceptional. However, we need to be careful about recognizing sedentary peoples as a norm in the last four hundred years. The proliferation of the migrants and refugees especially in the last two hundred years and the violent displacements and dislocations of millions of peoples should give us a pause to think twice before we accept states of sedentary peoples as a norm (Jones, 2016; see also Mazard, 2014). Moreover, Scott draws too sharp a difference between barbarians as nonstate peoples against state peoples. Yet, as he illustrates, barbarians included various peoples whose relationships to states were always in flux such peoples, as I have stated above, came in and out of various barbarian positions: nomads, savages, pirates, and others. That is one reason why I would prefer considering mobile peoples as 'transversal configurations' whose affiliations, belonging, affinities, and movements traverse and intersect various borders and boundaries, establish associations, assemblages, and solidarities through which they act as political subjects. Nonetheless, Scott's critique of the grand narrative of states as sedentary peoples gives us a longue durée historical ontology of mobile peoples that paints a very different picture.

If we are to see mobile peoples as a norm rather than an exception and as political subjects rather than subject peoples we need to start with an image of thought that sees how mobile peoples constitute themselves as political subjects not in bounded territories but through transversal configurations. This, as I said earlier, requires that we address the question how mobile peoples have become an exception in the first place. How did sedentary peoples became a norm that constituted mobile peoples as an exception? But, it also raises the question why we are now constituting mobile peoples as a norm. If indeed, we cannot appeal to autonomous facts concerning mobile peoples becoming a norm as it also reflects how we collect, collate, assemble, and interpret those facts. This means we cannot be outside the dynamic process that Hacking describes how kinds of people come into being: beginnings of a description, people acting under it, formation of institutions managing people acting under it, accumulation of knowledge about people acting under it, and regulation of people with expertise, authority, and power. If we are now making up mobile peoples as a norm rather than exception we are participating in this dynamic process through which mobile peoples are becoming political subjects of and subject to new modes of government.

\section{Acknowledgements}

This essay builds on a Leverhulme Doctoral Scholarship project proposal developed at Queens Mary University of London. I am grateful to all my colleagues across several schools and departments who commented on earlier versions of the proposal that we submitted to The Leverhulme Trust. I would like to thank especially Kim Hutchings and Jef Huysmans for helpful discussions that led to the development of the project. I am also grateful to my colleagues in the School of Politics and International Relations (SPIR) for their comments on a lecture based on this paper. I am also grateful to The Leverhulme Trust for allowing us to develop the project. I would like to thank the three anonymous reviewers for their helpful comments and criticisms and the editors of the thematic issue for their guidance.

\section{Conflict of Interests}

The author declares no conflict of interests.

\section{References}

Adey, P., Bissell, D., Hannam, K., Merriman, P., \& Sheller, M. (Eds.). (2014). The Routledge handbook of mobilities. London: Routledge.

Agamben, G. (2000). Means without end: Notes on politics (V. Binetti \& C. Casarino, Trans.). Minnesota: University of Minnesota Press.

Austin, J. L. (1962). How to do things with words. Oxford: Oxford University Press.

Badiou, A. (2016). Twenty-four notes on the uses of the word "people". In B. Bosteels \& K. Olson (Eds.), What is a people? (pp. 21-31). New York: Columbia University Press.

Boswell, C. (2009). The political uses of expert knowledge: 
Immigration policy and social research. Cambridge: Cambridge University Press.

Buscher, M., Urry, J., \& Witchger, K. (Eds.). (2011). Mobile methods. London: Routledge.

Canovan, M. (2005). The people. Cambridge: Polity.

Cresswell, T. (2006). On the move: Mobility in the modern Western world. London: Routledge.

Deleuze, G., \& Guattari, F. (1987). A thousand plateaus: Capitalism and schizophrenia. Minneapolis: University of Minnesota Press.

Elden, S. (2013). The birth of territory. Chicago: The University of Chicago Press.

Elliott, A., \& Urry, J. (2010). Mobile lives. London: Routledge.

Endres, M., Manderscheid, K., \& Mincke, C. (Eds.). (2016). The mobilities paradigm: Discourses and ideologies. London: Routledge.

Feldman, G. (2015). We are all migrants. Stanford, CA: Stanford University Press.

Foucault, M. (1997). What is enlightenment? (R. Hurley, Trans.). In Ethics: Subjectivity and truth (the essential works of Michel Foucault, 1954-1984) (Vol. 3, pp. 303-320). New York: New Press.

Frello, B. (2008). Towards a discursive analytics of movement: On the making and unmaking of movement as an object of knowledge. Mobilities, 3, 25-50.

Gabaccia, D. R. (1999). Is everywhere nowhere? Nomads, nations, and the immigrant paradigm of United States history. The Journal of American History, 86(3), 1115-1134.

Geiger, M. (2013). The transformation of migration politics: From migration control to disciplining mobility. In M. Geiger \& A. Pécoud (Eds.), Disciplining the transnational mobility of people (pp. 15-40). Basingstoke: Palgrave Macmillan.

Gold, S. J., \& Nawyn, S. J. (Eds.). (2013). Routledge international handbook of migration studies. London: Routledge.

Hacking, I. (2002). Historical ontology. Cambridge, MA: Harvard University Press.

Hacking, I. (2007). Kinds of people: Moving targets. Proceedings of the British academy, 151, 285-318.

Hannam, K., Mostafanezhad, M., \& Rickly-Boyd, J. M. (Eds.). (2016). Event mobilities: Politics, place and performance. London: Routledge.

Heidegger, M. (2012). Contributions to philosophy (of the event) 1936-38 (R. Rojcewicz \& D. Vallega-Neu, Trans.). Indianapolis: Indiana University Press.

Isin, E. F. (2002). Being political: Genealogies of citizenship. Minneapolis: University of Minnesota Press.

Isin, E. F. (2012). Citizens without nations. Environment and Planning D: Society and Space, 30(1), 450-467.

Isin, E. F. (2017). Performative citizenship. In A. Shachar, R. Bauböck, I. Bloemraad, \& M. Vink (Eds.), The Oxford handbook of citizenship (pp. 500-523). Oxford: Oxford University Press.
Isin, E. F., \& Nyers, P. (Eds.). (2014). Routledge handbook of global citizenship studies. London: Routledge.

Jones, R. (2016). Violent borders: Refugees and the right to move. London: Verso.

Laclau, E. (2005). On populist reason. London: Verso.

Lucassen, J., \& Lucassen, L. (2017). Migration over cultural boundaries: A rejoinder. International Review of Social History, 62(03), 521-535.

Lucassen, J., \& Lucassen, L. (Eds.). (2014). Globalising migration history: The Eurasian experience (16th-21st centuries). London: Routledge.

Manderscheid, K. (2016). Who does the move? Affirmation or deconstruction of the solitary mobile subject. In M. Endres, K. Manderscheid, \& C. Mincke (Eds.), The mobilities paradigm: Discourses and ideologies (pp. 91-113). London: Routledge.

Mazard, M. (2014). The art of (not) looking back: Reconsidering Lisu migrations and "Zomia". In J. Lucassen \& L. Lucassen (Eds.), Globalising migration history: The Eurasian experience (16th-21st centuries) (pp. 215-246). London: Routledge.

Merriman, P. (2012). Mobility, space, and culture. New York, NY: Routledge.

Nietzsche, F. W. (2001). The gay science: With a prelude in German rhymes and an appendix of songs. Cambridge: Cambridge University Press.

Osterhammel, J. (2009). The transformation of the world: A global history of the nineteenth century (P. Camiller, Trans.). Princeton: Princeton University Press.

Panayi, P., \& Virdee, P. (Eds.). (2011). Refugees and the end of empire: Imperial collapse and forced migration in the twentieth century. Basingstoke: Palgrave Macmillan.

Pécoud, A. (2015). Depoliticising migration: Global governance and international migration narratives. Basingstoke: Palgrave Macmillan.

Rancière, J. (1995). On the shores of politics (L. Heron, Trans.). London: Verso.

Rancière, J. (1998). Disagreement: Politics and philosophy (J. Rose, Trans.). Minneapolis, MN: University of Minnesota Press.

Scott, J. C. (1999). Seeing like a state: How certain schemes to improve the human condition have failed. New Haven: Yale University Press.

Scott, J. C. (2009). The art of not being governed: An anarchist history of upland Southeast Asia. New Haven: Yale University Press.

Scott, J. C. (2017). Against the grain: A deep history of the earliest states. New Haven: Yale University Press.

UN. (2015, 12 January). 244 million international migrants living abroad worldwide, new UN statistics reveal. Retrieved from http://wp.me/p5Mdaw-3EG

Zanoni, E. (2017). Thinking big about mobile people. Journal of American Ethnic History, 37(1), 57-64. 


\section{About the Author}

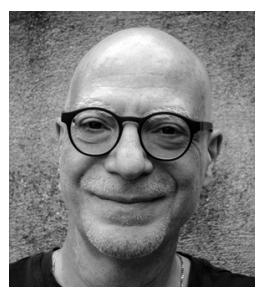

Engin Isin is Professor of International Politics, Queen Mary University of London (QMUL) and University of London Institute in Paris (ULIP). Engin's research and teaching focus on doing politics-the ways in which people constitute themselves as actors or subjects of politics through performances, movements, and struggles. 